\title{
Characteristics of Functional Constipation among Kindergarten Students in Kecamatan Jatinangor, West Java, Indonesia
}

\author{
Livia Giovanni, ${ }^{1}$ Yudith Setiati Ermaya, ${ }^{2}$ Tisnasari Hafsah ${ }^{2}$ \\ ${ }^{1}$ Faculty of Medicine Universitas Padjadjaran, ${ }^{2}$ Department of Child Health Faculty of Medicine \\ Universitas Padjadjaran/Dr Hasan Sadikin General Hospital Bandung Indonesia
}

\begin{abstract}
Background: Functional constipation can occur in children and affect their quality of life, but there is still lack of awareness and inability to provide proper management. Therefore, early detection is important. The aim of this study was to identify the prevalence of functional constipation among kindergarten students and its risks.

Methods: A quantitative descriptive study was conducted from April to May 2017 on kindergarten students in Kecamatan Jatinangor, West Java, Indonesia by using questionnaires for their parents. In total, 149 parents joined the study. The questionnaire was made based on the Rome IV Criteria with additional questions for the student's characteristics comprised of sex, prematurity, allergy, family history of constipation, dietary fiber consumption, and parents' education level. Descriptive analyses were conducted.

Results: The prevalence of functional constipation among the students was $8.7 \%$ with the most frequent complaints were retentive posturing (76.9\%), hard stool consistency (38.5\%), and history of obstructing toilet by stool (38.5\%). Characteristics of children with functional constipation were prematurity (15.4\%), history of allergy (15.4\%), low dietary fiber intake (from fruits, $69.2 \%$, vegetables $84.6 \%$, seeds $100 \%$ ), and non-university educated parents (father $76.9 \%$, mother $84.6 \%$ ).
\end{abstract}

Conclusions: Constipation among kindergarten students in Jatinangor is $8.7 \%$, while the most apparent characteristics in constipated children is low dietary fiber intake.

Keywords: Functional constipation, kindergarten students, prevalence

\section{Introduction}

Functional constipation commonly occurs in children worldwide $(0.7-29.6 \%){ }^{1}$ A study on kindergarten students in $\mathrm{Bali}^{2}$ showed a percentage of $15.1 \%$. Patients with functional constipation have various signs and symptoms causing a decrease in quality of life. Functional constipation in children can cause learning problems, adaptation difficulty, and minor psychological disorder. ${ }^{3}$

The early detection of functional constipation is therefore needed. Meanwhile, parents rarely bring their children for any possible signs and symptoms of functional constipation to a doctor due to the lack of awareness towards the problem and the importance of proper management. Any complaints resembling constipation are usually treated based on local and generational beliefs, as well as self-trial and error with their efficacy unproven. Therefore, children are often brought to the hospital in a more serious condition. The aim of this study was to identify the prevalence of functional constipation and its risks.

\section{Methods}

A descriptive study was carried out to parents of kindergarten students in Jatinangor subdistrict West Java, Indonesia from April 2017 to May 2017. There were 17 kindergarten schools in Jatinangor subdistrict, with the number of students of each school ranging from 16 to 99 students. After considering the location of the school and the number of students in the school, 5 schools were selected. The inclusion criteria of the participants of this study were parents whose children studied in

Correspondence: Livia Giovanni, Faculty of Medicine, Universitas Padjadjaran, Jalan Raya Bandung-Sumedang Km.21, Jatinangor, Sumedang, Indonesia, Email: livia0697@gmail.com 
those selected kindergarten. The exclusion criteria were parents with children who were under 4 years old, children with neurological, metabolic, or endocrine problems or in treatment phase with opioids, anticonvulsants, antidepressants, or anticholinergic drugs. A total of 220 parents of kindergarten students from those schools were selected to participate in this study. Prior to the data collection, the selected parents were given explaination about the study, and those who understood and agreed to join the study were given informed consent form to be signed.

Every participant was given a set of questionnaire which was divided into 2 parts, that comprised of the student's general data, to explore the characteristics, and 7 questions as the diagnostic tool for functional constipation. The first part explored the characteristics of the parents and the children, consisted of questions about name, sex, place and date of birth, address, number of children in the family, history of prematurity, allergy, family history of defecation difficulty, dietary fiber consumption, and general data of the parents, especially the education level. The second part explored their children's experience in defecation, i.e. the frequency of bowel movements, stool consistency, pain with bowel movements, history of obstructed toilet by stool, retentive posturing, palpable stool in abdomen, and soiling. The second part of the questionnaire was generated from the Rome IV Diagnostic Questionnaire for Pediatric Functional Gastrointestinal Disorders for Children and Adolescents section $\mathrm{C}$ that was translated into Bahasa Indonesia. The students were categorized as constipated if they experienced at least 2 criteria listed in the Rome IV Criteria in the last one month. A total of 149 from 220 completed questionnaires were eligible to be analyzed.

The collected data was expressed in numbers and percentages, and presented in tables. This study was carried out with the permission of the Health Research Ethics Committee Faculty of Medicine Universitas Padjadjaran with ethical exemption No:459/ UN6.C.10/PN/2017.

Table 1 Differentiation Characteristics of the Subjects

\begin{tabular}{|c|c|c|c|}
\hline Characteristics & & $\begin{array}{c}\text { Constipated } \\
(n=13)\end{array}$ & $\begin{array}{l}\text { Unconstipated } \\
(n=16)\end{array}$ \\
\hline \multirow[t]{2}{*}{ Sex } & Male & $4(30.8 \%)$ & $70(51.5 \%)$ \\
\hline & Female & $9(69.2 \%)$ & $66(48.5 \%)$ \\
\hline \multirow[t]{2}{*}{ Prematurity } & Preterm & $2(15.4 \%)$ & $5(3.7 \%)$ \\
\hline & Term & $11(84.6 \%)$ & $131(96.3 \%)$ \\
\hline \multirow[t]{2}{*}{ Allergy } & Yes & $2(15.4 \%)$ & $14(10.3 \%)$ \\
\hline & No & $11(84.6 \%)$ & $122(89.7 \%)$ \\
\hline \multirow[t]{2}{*}{ Family history of constipation } & Yes & $0(0 \%)$ & $7(5.1 \%)$ \\
\hline & No & $13(100 \%)$ & $129(94.9 \%)$ \\
\hline \multicolumn{4}{|l|}{ Dietary fiber consumption } \\
\hline \multirow[t]{2}{*}{ Fruits } & Not Everyday & $9(69.2 \%)$ & $94(69.1 \%)$ \\
\hline & Everyday & $4(30.8 \%)$ & $42(30.9 \%)$ \\
\hline \multirow[t]{2}{*}{ Vegetables } & Not Everyday & $11(84.6 \%)$ & $89(65.4 \%)$ \\
\hline & Everyday & $2(15.4 \%)$ & $47(34.6 \%)$ \\
\hline \multirow[t]{2}{*}{ Seeds } & Not Everyday & $13(100 \%)$ & $120(88.2 \%)$ \\
\hline & Everyday & $0(0 \%)$ & $16(11.8 \%)$ \\
\hline \multirow[t]{2}{*}{ Paternal Last Education } & Non-university Educated & $10(76.9 \%)$ & $95(69.9 \%)$ \\
\hline & University Educated & $3(23.1 \%)$ & $41(30.1 \%)$ \\
\hline \multirow[t]{2}{*}{ Maternal Last Education } & Non-university Educated & $11(84.6 \%)$ & $87(63.9 \%)$ \\
\hline & University Educated & $2(15.4 \%)$ & $49(36.1 \%)$ \\
\hline
\end{tabular}


Table 2 Rome IV Criteria for Children with Functional Constipation

\begin{tabular}{lcc}
\hline \multicolumn{1}{c}{ Complaints } & Frequency & Percentage \\
\hline Frequency of bowel movements 2 per week or less & 4 & $30.8 \%$ \\
Stool consistency & 5 & $38.5 \%$ \\
Pain with bowel movements & 3 & $23.1 \%$ \\
History of obstructed toilet by stool & 5 & $38.5 \%$ \\
Retentive posturing & 10 & $76.9 \%$ \\
Palpable stool in abdomen & 0 & $0 \%$ \\
Soiling & 4 & $30.8 \%$ \\
\hline
\end{tabular}

\section{Results}

This study discovered that the prevalence of functional constipation among kindergarten students was $8.7 \%$ (13 out of 149 students). Based on their characteristics, this study revealed that females, had term birth history, no history of allergy, no family history of constipation, and non-daily dietary fiber consumption (fruits $=69.2 \%$, vegetables $=84.6 \%$, seeds $=100 \%$ ), were the most frequent who had functional constipation.

Moreover, the complaints experienced by constipated students showed retentive posturing as the most frequent complaint experienced by 10 out of 13 students (Table 2).

\section{Discussion}

This study showed constipation among kindergarten students with a prevalence of $8.7 \%$. This prevalence was lower than the percentage of $15.1 \%$ from a previous study in Bali. ${ }^{2}$ This result was also in the range of worldwide prevalence of constipation in pediatric population published by the World Health Organization (WHO) (0.7-29.6\%).1 In the United Stated of America (USA) ${ }^{4}, 10 \%$ prevalence rate has been reported, and studies from Europe ${ }^{5}$ showed prevalence rates ranging from $0.7 \%$ to $15 \%$. In Taiwan ${ }^{6}$, functional constipation has been reported in $33.3 \%$ of elementary students, $12 \%$ to $28 \%$ in Hong Kong $^{7}$ and South Korea ${ }^{8}$ and $7 \%$ to $15 \%$ of school children in Sri Lanka. ${ }^{9}$ These differences might be due to difference in lifestyle, especially because of the dietary habit, age range of children who was included, duration of study, and the instruments used to detect the symptoms of functional constipation.

Based on the Rome IV Diagnostic Questionnaire for Pediatric Functional Gastrointestinal Disorders for Children and Adolescents section C, most common complaints experienced by children with functional constipation in this study were retentive posturing $(76.9 \%)$, compared to hard stool consistency (38.5\%), history of obstructed toilet by stool (38.5\%), frequency of bowel movements was 2 per week or less (30.8\%), painful bowel movements $(23.1 \%)$, and soiling (30.8\%). There was no student with history of palpable stool in abdomen. The percentages presented above were relatively different compared to the previous study performed in pediatric gastroenterology clinics in Korea by Chang et al. ${ }^{10}$ which showed hard stool consistency, painful bowel movement, and a history of large stools in the lower abdomen as the most common complaints with the percentage of $60 \%, 60 \%$, and $68 \%$ consecutively. Another study from Korea which was performed in several daycare centers by Park et al. ${ }^{11}$ showed painful defecation $(55.6 \%)$ and retentive posturing $(50 \%)$ as the most common complaints experienced by constipated children, followed by the presence of a large fecal mass in the rectum (44.4\%), frequency of bowel movements was 2 per week or less $(44.4 \%)$, and obstructed toilet by large stool (38.9\%), with the least common complaints were soiling once or more per week $(27.8 \%)$. All these studies showed that one out of three most common experienced complaints in children with functional constipation was hard stool consistency.

In exploration of the characteristics, the constipation group was dominated by female. The study by Chang et al. ${ }^{10}$ showed similar result, with $56 \%$ of females in the constipation group. This aroused suspicion that there might be correlation between sex and functional constipation. Nevertheless, the previous study by Park et al. ${ }^{11}$ did not show any correlation between them.

Moreover, other factors suspected to have association with functional constipation were 
prematurity and allergy. Out of the total of 13 students who were detected to have functional constipation, 2 students were born premature. A previous study in Turkey ${ }^{12}$ showed that prematurity was seen more frequently in constipated children compared to unconstipated children, while the other study in Korea ${ }^{11}$ showed no correlations between gestational week and functional constipation. The correlation, if any, might probably be due to the gestational age which is related to the development process of the nervous system in the digestive tract. History of allergy was found in $15.4 \%$ of children in the constipated group. Rajindrajith et al. ${ }^{13}$ stated that one of the risk factors for functional constipation in children was cow's milk protein allergy.

The majority of children with functional constipation had parents with nonuniversity based education (father $=76.9 \%$, mother $=84.6 \%$ ) This result might suggest that education of parents correlated with functional constipation prevalence. The level of education might probably affect eating habits they applied to their children. Currently, a bad eating habit is one of many problems frequently faced by kindergarten students. This study showed that low dietary fiber intake seemed to relate to higher number of constipation cases. In the constipated group, 9 students did not consume fruits daily $(69.2 \%)$, 13 students did not consume seeds daily $(100 \%)$ and 11 students did not consume vegetables daily $(84.6 \%)$. The previous study in Korea ${ }^{11}$ and Turkey ${ }^{12}$ shared similar results. However, there might be a misperception when the respondents were asked about seeds, since seeds are not commonly consumed by Indonesians. Most of the respondents thought that seeds and nuts were the same but it was actually different. Nuts are well-known for its protein, while seeds are well-known for its fiber content.

Family history as one of the predisposition factors for functional constipation in children had a contradictive result in this study. There was no constipated child with a family history of constipation, while the previous studies showed correlation between family history of constipation and functional constipation in children. ${ }^{2,11,12}$

This study had several limitations. Variables obtained in this study were superficial, for example in the determination of prematurity, history of dietary fiber intake, history of allergy, etc.might cause bias. The other limitation was the minimum amount of samples, which was targeted as many as 197 respondents, was not obtained due to the time of data retrieval. The data was collected near the end of the academic year, when the study process was ineffective; therefore, many students did not attend school. Meanwhile, it was difficult to make home visits for obtaining data due to the duration and location access limitations. Lastly, this study was a descriptive study, so it could not confirm any correlations between the variables and constipation. Therefore, a further analytical study with a larger sample size should be carried out to prove the possible hypotheses mentioned above.

In conclusion, the prevalence of constipation among kindergarten students in Kecamatan Jatinangor is $8.7 \%$, with low dietary fiber intake as the most apparent characteristic. A further analytical study should be performed to find the correlation between the incidence of constipation and the characteristics, so that it may gain more significant information.

\section{References}

1. Mugie SM, Benninga MA, Di Lorenzo C. Epidemiology of constipation in children and adults: a systematic review. Best Pract Res Clin Gastroenterol. 2011;25(1):3-18.

2. Eva F. Prevalensi konstipasi dan faktor risiko konstipasi pada anak [thesis]. Denpasar: Universitas Udayana; 2015.

3. Rajindrajith $S$, Devanarayana NM, Crispus Perera BJ, Benninga MA. Childhood constipation as an emerging public health problem. World J Gastroenterol. 2016;22(30):6864-75.

4. Wald ER, Di Lorenzo C, Cipriani L, Colborn DK, Burgers R, Wald A. Bowel habits and toilet training in a diverse population of children. J Pediatr Gastroenterol Nutr. 2009;48(3):294-8.

5. Kiefte-de Jong J, Escher J, Arends L, Jaddoe V, Hofman A, Raat H, et al. Infant nutritional factors and functional constipation in childhood: the Generation R study. Am J Gastroenterol. 2010;105(4):940-5.

6. Wu T-C, Chen L-K, Pan W-H, Tang R-B, Hwang S-J, Wu L, et al. Constipation in Taiwan elementary school students: a nationwide survey. J Chin Med Assoc. 2011;74(2):57-61.

7. Tam YH, Li AM, So HK, Shit KY, Pang KK, Wong YS, et al. Socioenvironmental factors associated with constipation in Hong Kong children and Rome III criteria. J Pediatr Gastroenterol Nutr. 2012;55(1):56-61.

8. Lee WT, Ip KS, Chan JS, Lui NW, Young BW. Increased prevalence of constipation 
in pre-school children is attributable to under-consumption of plant foods: A community-based study. J Paediatr Child Health. 2008;44(4):170-5.

9. Rajindrajith S, Devanarayana N, Adhikari C, Pannala W, Benninga M. Constipation in children: an epidemiological study in Sri Lanka using Rome III criteria. Arch Dis Child. 2012;97(1):43-5.

10. Chang SH, Park KY, Kang SK, Kang KS, Na SY, Yang HR, et al. Prevalence, clinical characteristics, and management of functional constipation at pediatric gastroenterology clinics. J Korean Med Sci. 2013;28(9):1356-61.
11. Park M, Bang YG, Cho KY. Risk factors for functional constipation in young children attending daycare centers. J Korean Med Sci. 2016;31(8):1262-5.

12. Kocaay P, Eğritaş O, Dalgic B. Normal defecation pattern, frequency of constipation and factors related to constipation in Turkish children 0-6 years old. Turkish J Gastroenterol. 2011;22(4):369-75.

13. Rajindrajith $S$, Devanarayana NM. Constipation in children: novel insight into epidemiology, pathophysiology and management. J Neurogastroenterol Motil. 2011;17(1):35-47. 